\title{
COVID-19 and religion: risks and opportunities
}

Danilo Buonsenso ${ }^{1,2,3}$, Grazia Leuconeo Sisti $^{3}$, Umberto Moscato ${ }^{1,3}$, Walter Malorni ${ }^{3}$,on behalf of the Center for Global Health Research and Studies

${ }^{1}$ Department of Woman and Child Health and Public Health, Fondazione Policlinico Universitario A. Gemelli IRCCS, Rome, Italy

${ }^{2}$ Dipartimento di Scienze Biotecnologiche di Base, Cliniche Intensivologiche e Perioperatorie, Università Cattolica del Sacro Cuore, Rome, Italy;

${ }^{3}$ Center for Global Health Research and Studies, Università Cattolica del Sacro Cuore, Rome, Italy

\section{Corresponding author}

Danilo Buonsenso

danilobuonsenso@gmail.com

+393319819715

Twitter: surf4children 


\begin{abstract}
Culture, gender and religion are closely linked each other's, profoundly affect the role of each person within the Society, and also affect the ability to access to the health resources. We are now living a worldwide crisis due to the SARS-CoV-2 pandemic. In order to appropriately tackle it, an alliance between science, politics and citizens is needed. In this article, we summarize current evidences of how religions can represent, on one hand, a risk moment for spreading the virus (in relation with overcrowded events), on the other, a precious opportunity to engage people, and in particular minorities, in fighting the pandemic. To win this fight, we need a multicultural approach that takes into account every aspect of human life, and among these religion, which influences so much culture, everyday life and well-being.
\end{abstract}




\section{Introduction}

Culture, gender and religions contribute to determine the role of each individual within a Society and, therefore, represent important variables that may influence the ability of the single person to access the health resources offered by the community (1).

For each culture, it is important to establish the role that each individual occupies within the society. This role in some societies can be established from birth, by belonging to castes or closed social groups, in other societies it is attributed on the basis of the class of belonging, income or profession exercised (1). In every culture and in every society there is, however, a fundamental reference to the role that is assigned to the two genders, and this role has in turn, over the centuries, been strongly influenced by Religions.

The development of male and female roles in every society is, in fact, not defined by the sex they belong to but always happens in an arbitrary way. For example, motherhood is different from maternal function: the first is defined by sex, the second is arbitrarily attributed to the woman (parental care).

In every society, the construction of gender roles takes place through a long learning process that begins in childhood, assigning different models of behavior, obligations and rights to the two biological sexes (2). We are born male or female (sex), but in the course of life we become men and women (gender), only after adopting different behaviors, influenced and regulated by the social context in which we live (2). Religion has a fundamental role in the construction of gender models in all populations and has determined, and still partly determines, the different placement of the two genders within the societies (3). If gender and culture have a known impact on health, not only in terms of gender-related biological risk of specific pathologies, but also in terms of access to care, and gender and culture are strongly intertwined to millenary religious influences, it goes without saying that the link between religion and disease is closer than one might think.

This concept is particularly important in modern times, when migratory flows have led to the birth of large multicultural urban areas, made up of people of different ethnicities, cultures and religions who need to interplay with social, economic and health resources different from those they were used to in the countries of origin. In fact, culture of origin and religious faith tend to persist and to be handed down from generation to generation even when situations change and a person encounters other realities. Religion, in particular, assumes, in this case, also an important identity role for the groups of populations moving to other countries. Immigration separates individuals from family, relatives and friends in a traumatic way. The religious meetings organized in the host country become important, because they represent a precious opportunity to meet compatriots. The discovery of 
elements that recall the homeland and the memory of the past, together with the opportunity to cultivate social relationships and to frequent other compatriots, are factors that nourish participation in religious communities and determine the continuation of concepts, beliefs and convictions of people's own country of origin. Among these beliefs and convictions, a preponderant role is covered by the concept of Health and Disease.

\section{Religion, health and disease}

The concepts of health and disease have deep roots in religious beliefs with a consequent plurality of behaviors, which must be constantly investigated and considered, particularly during a pandemic when people behaviors may positively or negatively impact on disease control. Considering how much religion can influence culture, it is important to be aware of traditional concepts that link religions with disease, since these concepts may affect the responses of some categories of believers when in time of health crisis.

In Judaism, the disease is considered as a failure to observe the divine provisions and therefore it is the consequence of a poor protection of the person with regard to prevention and treatment, and must be accepted as part of one's nature and as proof sent by God (4). The concept does not substantially change in Christianity, which sees in Jesus a physician of the body as much as of the soul, whose miracles are above all medical successes. For Islam, prevention is fundamental, since the disease is evidence of a state of imbalance of the individual as a whole and therefore an instrument of selfcriticism and drive for both spiritual and physical improvement. In Eastern Religions, well-being is the result of the harmony of the person, not only on an individual level but also in relation to the environment in which they live, while illness is a stimulus for regaining this harmony (5).

Sexuality (6-8), abortion (9) and assisted fertilization (11) follow very precise and rigid rules dictated mainly by the Religion to which a person belongs.

Some rules that Religions reserve for their devotees may in certain cases prevent the intervention of the health workers themselves: religion forbids transfusions for Jehovah's Witnesses, for Sikhs it is prevented cutting hair and hair with repercussions in case of surgery that instead requires hair removal for infection control (11).

There are also Religious rules for the end of life, for burial, autopsies, or organ donation $(11,12)$. For Hinduism, cremation must take place immediately after death, while for Adventist Christians the body cannot be touched until entombment; this can prevent, in both cases, any type of resuscitation practice. For Hindus the anxiety of prolonging life as much as possible, denying imminent death is 
an undoubted consequence of the illusion of immortality. A Hindu patient prefers to face death in a conscious and lucid state, therefore often refuses the administration of drugs that could cloud or cloud the mind. Autopsy is usually not accepted. Islam concepts see death as something predestined by God and consequently accept both death and disease as a natural path of life. Islam considers human life sacred, so suicide and euthanasia are prohibited, however, if a patient finds himself in a condition in which he has no life expectancy, the interruption of medical care is allowed. For Jews, the sacredness of life prohibits any form of euthanasia, which is also condemned by Buddhism and considered unacceptable by the Orthodox Church. Jehovah's Witnesses do not accept suicide and support all efforts to extend life however, forgoing treatment where death is clearly imminent or inevitable does not result in any violation of God's law.

In case of illness, a substantial distrust towards Western medicine is sometimes evident, especially in the part of groups belonging to Eastern religions who continue to follow the traditional medicines of their country or who associate them with the evidence-based therapies included in modern guidelines (1-4). In the latter case, less trust to "western medicine" could hamper the attitude of these people to access health services, leading to a non-use of all resources offered by the health systems.

Importantly, religions can also have impact on positive attitudes: some are linked with healthier attitudes such as lower abuse of drugs and alcohol, healthier life-stiles and regular physical activity.

In general, the different religious confessions undoubtedly present gender-specific problems, complicated by the intertwining with the culture of origin, which make the relationship with health professionals difficult $(8,11)$. For example, it may happen that men do not want to request assistance in case of illness, because it is considered a weakness with respect to the role that their gender plays in the social group. It is also established that Hindu women are generally reluctant to go to the doctor and be examined and that, if pregnant, they only go to the doctor when the delivery is close (8). Buddhist women prefer to be assessed by female staff, while monks cannot be evaluated by a female doctor (in the East, hospitals have areas reserved for monks only) (10). Populations from some Muslim countries do not accept being examined or treated by doctors or other health personnel who are not of the same sex. In this context, it is important to be aware that sex itself is a determinant of health and use to health resources.

There is also very serious evidence of the persistence of cultural and religious surgical practices in the host country (i.e. circumcisions and partial or total female genital mutilation), carried out at home with improper tools in precarious hygienic conditions, which seriously endanger the lives of minors, with the consequent presentation to the structures of local health systems of cases to be treated as emergencies. 
How does this deep link between disease and religion interface with the COVID-19 pandemic we are experiencing? This is a relevant question if we consider that infectious diseases are historically much more "close" to Gods than other diseases. Infectious diseases, with leprosy being a very classic example, were traditionally considered a sign of impurity and were a reason for divine punishment and social exclusion. If we consider how COVID-19 is catalyzing all attentions of media and public opinion, and consuming most resources of national health systems moving the "other non-COVID19 diseases" to the background, we can imagine better how religions can affect human behavious during the pandemic.

\section{COVID-19 and Religion: risks}

Religious events are traditionally characterized by mass of people meeting in specific environments to pray or meditate. Frequently, these events are long lasting and held in closed spaces. Some rituals include also a physical contact such as the hand sharing in "sign of peace" in Catholic churches. Therefore, theoretically, such events bear a substantial risk of SARS-CoV-2 spread within the community. Previous outbreaks showed us that this risk is possible. During the 2009 H1N1 influenza A and Middle East respiratory syndrome coronavirus (MERS-CoV) outbreaks, face mask use was low among pilgrims and, interestingly, the outbreaks coincided with the Hajj (13). Not by a chance, a risk for large-scale religious events being triggers of the pandemic was already highlighted on the Lancet back on March (13). Unfortunately, the suspicion has been confirmed by a number of outbreaks clearly related to religious events.

In Albania, SARS-CoV-2 infected more than 100 people who went to a funeral, fuelling an outbreak that involved the surrounding rural county (14). In Arkansas, an infected pastor infected more than 30 attendees at church events, leading to three related deaths and a subsequent infection of 26 more people, one of whom died $(15,16)$. In Saudi Arabia, the returning Saudi pilgrims who visited pilgrimage sites in Iran and Iraq have been suggested to be the early source of community spreading of SARS-CoV-2 (17). Luckily, as soon the pandemic began worsening, the Kingdom of Saudi Arabia, on 27 February 2020, placed restrictions on inbound Umrah pilgrimage for the first time in the eight decades of the history of Muslim pilgrimage (18). Probably, restrictions have been decided too late. Also Pakistan did not stop religious travellers at the beginning. On March $24^{\text {th }}$, 2020, Pakistan reported 990 cases, sixty percent of them being pilgrims who travelled to Iran (19). The same happened in Iran, where several cases within the country and dozen neighbouring countries has been linked to main pilgrimage events $(20,21)$. In Greece, 48 out of $53(90.5 \%)$ pilgrims which visited Jerusalem on February $19^{\text {th }}$ tested positive (22). In Guangzhou, China, SARS-CoV-2 infection was diagnosed in six passengers returning from a pilgrimage at a masjid in Pakistan. These pilgrims spent 
the previous weeks in close contact with thousands of pilgrims at the masjid, without wearing face masks, having potentially infected a large number of people (23). In Malaysia, more than 19000 people of different nationalities attended the Sri Petaling gathering, a Moslem missionary movement, in March 2020 in Kuala Lumpur. 1701 samples have been tested positive and, later, 35\% of new COVID-19 cases reported in the country were linked to this gathering (24). This apparently acted as a source of the infection for the subsequent two gatherings in Pakistan and India, because the infected Malaysians attended those assemblies (25). In India, by April 4, 2020, 1023 people linked to this congregation tested positive across the country (26). Another outbreak in the northwestern Indian state of Punjab was linked with a 70 year-old Sikh priest who, after returning from Italy and Germany, refused to be self-quarantine and attended several religious meetings including a Sikh festival attracting 300,000 people every day. He died of COVID-19 (27). In the Eastern Cape Province, South Africa, as of the 7th of May 2020, about $80 \%$ of the infections in the province resulted from three burial ceremonies in Port St Johns, Port Elizabeth and Mthatha. In the Free State province, a single religious event lead by three positive church leaders led to the infection of over 80 persons and the further tracing of 1,600 people who may have been exposed to the virus (28).

In Italy, more than 100 priests died of COVID-19 and several more have been hospitalized. In several Italian hospitals, nurses and doctors have been instructed by hospital's manager to give the blessing to those who want it and to those who are dying, due to the shortage of hospital chaplain (29).

Although there are no studies proving a direct link with religious activities, COVID-19 infection rates among the ultra-orthodox Jews of Israel were significantly higher than those reported in other Israelis (30). Although the crowded living conditions may in part explain this difference, the attendance of communal religious prayers (in particular the Jewish holiday of Purim on March 9, 2020) may have contributed (31). In London, a thousand devotees of the International Society for Krishna Consciousness attended a funeral at its temple on March 21, 2020. Twenty-one of them tested positive, five died (32). A similar outbreak happened in Italy, in the Molise Region, after a Rom funeral (33).

Another potential risk can be related to the use of unofficial treatments. For example, there are descriptions of believers drinking cow urine and hosting cow urine drinking parties to cure COVID19, or combining and consuming water and sacred soil found at the grave of Maronite monk Mar Charbel (Mount Lebanon) (34).

Another scenario to consider during the pandemic, still related with religious practices, is how fasting can affect the severity of an eventual SARS-CoV-2 infection. Currently, while positive effects of intermittent fasting on otherwise healthy people have been shown (35) (36), undernourishment could 
be dangerous in acute viral diseases (36). Some authors proposed a practical approach suggesting to fasting or not according to the baseline patients conditions (37), highlighting the need of future studies to better address this topic. Considering the severity of current epidemiological situation, during the next Ramadan the SARS-CoV-2 will be still among us and millions of religious will be fasting. Therefore, clarifying this aspect is still a priority.

Also, the pandemic can also fuel religious discriminations. Examples of anti-semitic attitudes iarethe beliefs that the Jews developed the virus in order to later gain credit and profit from the vaccine that they would develop. Another anti-semitic belief is that the pandemic is a punishment for Jewish denial of Jesus. Also, there has been an $18 \%$ rise in anti-semitic incidents worldwide since the beginning of the pandemic (38).

\section{COVID-19 and Religions: opportunities}

Religious meetings represent meaningful moments for believers and may be particularly important for minorities not living anymore in their home country. For example, Black Churches have a well known role in promoting spiritual renewal and mental resiliency and coping against societal racism, especially for older African Americans (39). The closure of these settings may contribute to more isolation of these communities and increase healthcare inequities. A proactive engagement of these communities and religious leaders may guarantee a proper and trusted communication about how to appropriately deal with the pandemic (39). This is why a global partnership between Governments, Health Systems and all Religions may support the fight against the COVID-19 pandemic, promoting interreligious/interfaith dialogue during these times. Such a dialogue would allow a more concrete support of poor communities and active engagement of minorities in order to limit the spread of the virus (40), since for some religious practitioners the imposition of restrictions, including church closures, may be linked to restrictions to adhere to the preventive measures (41). Religious institutions already played a role to defeat Ebola in west Africa (42). A comprehensive, proactive and multidisciplinary approach gains more importance if we consider that surveys showed that the faith of US adults became stronger during the pandemic, particularly among black Americans and Hispanics (44), and in general the Google searches for prayers grew of more than $50 \%$ than the prepandemic period (44). An online survey made in US, showed how Jewish community organizations were trusted more than any other source of COVID-19-related information, and they received more concrete supports, such as food delivery, social support, virtual religious services, and dissemination of COVID-19-related information, by local religious congregations. A Survey of 419 American Orthodox Jew showed that a positive religious attitude, intrinsic religiosity and trust in God strongly 
correlated with less stress and more positive impact in terms of respect of COVID-19 related measures (45). These surveys further show the potential role of religious community in engaging communities, in particular minorities, and in having their partnership in respecting proper rules (46). Religious services can be utilized in disseminating precautionary measures and to follow evidence based practices against the COVID-19 $(45,47,48)$.

Proactive activities have been already developed in some settings. In Sao Paulo, a spiritual hot line has been developed on May and during the first two weeks 108 appointments were requested and calls were made from 107 Brazilian states and 2 countries (Brazil and Portugal) (49), highlighting the potential utility and interest of such a project. Small communities worldwide also organized the Jewish holiday of Pesach (or Passover), Ramadan, Easter, or even funerals through online platforms (50,51), still confirming how important certain ceremonies are for several people from the most different cultures, highlighting the meaning of religious moments and how these events and religious leaders can positively engage people. In the Philippines, Catholic congregations organized online ceremonies and provided online counselling and guidance, and also distributed free protective equipment and food to poor and homeless (52). Similar support services have been also established in Detroit (53).

Considering the major impact COVID-19 has on older people, which are usually also those most religious in the communities (54), geriatric psychiatrists believe that faith may support older patients to relieve anxiety during this COVID-19 pandemic (55), and healthcare workers should be aware of it. Even the World Health Organization clearly recognizes the importance of interventions by chaplains to support the healing process of religious patients $(56,57)$.

\section{Future perspectives}

These considerations imply the need for a geographic and phenomenological approach in the evaluation of the strategies to be implemented in terms of prevention, access to treatment, therapeutic interventions. An approach of this type, albeit always valid, is the higher priority in these times, with an out-of-control pandemic and growing numbers of infections and deaths, despite attempts by governments to stem the spread of the virus with restrictive measures. We need a new approach which puts the culture of the populations at the center, which makes them protagonists and participants, making them take an active role rather than passively undergo political decisions. It is therefore also necessary to address the problems concerning the social role reserved for individuals belonging to different sexes, confessions and cultures. The knowledge of these critical issues can offer the tools necessary to ensure the overcoming of any discrimination and give an adequate offer by health systems to all residents of the national territories. 
An obvious example regards the relationships between ultraorthodox and COVID-19. UltraOrthodox, or Haredi Jewish communities, are a specific population with peculiar and strict rules. For example, internet access, television broadcasts and some cellphone functions are limited and this "closeness to God" prevented many of them from being updated on the severity of the first wave of COVID-19 (58). This is a classic population that would be reached and engaged only with a close, proactive partnership with their rabbis.

These interventions must necessarily be carried out through the establishment of collaborative relationships with all those social or territorial organizations of all kinds that are already working for the integration of populations belonging to different ethnic groups and religious confessions, as also highlighted by an International Statement (59). In the context of the fight against health inequalities, policy makers and health organizations at all levels must intervene on the barriers that limit access to the services offered by the health system. In light of the influence of religion on peoples' cultures, in particular on minorities who emigrated to new countries, it becomes necessary to establish an interreligious and pluri-cultural collaboration and a training and information relationship (including health aspects), bringing together exponents of different religious denominations, including Buddhists and those belonging to Reformed Christianity, Judaism, Hinduism, Islam, Christian Orthodox.

This process would allow the activation of information and training courses for health workers to allow: to assess patients in an intercultural and pluri-religious dimension; to activate pathways for adapting care and assistance procedures in health facilities; to create specific materials aimed at the acquisition of knowledge and skills for the humanization of care in multicultural and multi-religious realities. In turn, religious organizations can act as intermediaries to reach communities that may have all kind of difficulties in accessing health services, or resistance to the implementation of preventive measures for the spread of the virus.

In terms of the pandemic, difficult months await us. To tackle it, an alliance between science, politics and citizens is needed. To reach the latter and actively involve them in this process, we need a multicultural approach that takes into account every aspect of human life, and among these religion, which influences so much culture, everyday life and illness.

Achnowledgements: The Center for Global Health Research and Studies: Stefano Vella, Chiara Bertolaso, Maria Luisa Ricciardi, Walter Ricciardi. The center is also grateful to dr. Cristina De Rose for its contribution for the revision of manuscripts.

\section{References}


1- Giovanni C, Pagano MT, Dupuis ML, Malorni W, La Rocca C. Salute, Genere e Religioni. ISBN 978-88-255-xxxx-x. DOI 10.4399/97888255xxxxx11

2- Nedelmann B, s.v. Ruoli maschili e femminili, in Enciclopedia delle scienze sociali, Treccani, Roma, 1997.

3- Biale D. Eros and the Jews: from biblical Israel to contemporary America, Basic Books, New York 1992.

4- Dorff E. The Jewish Tradition: religious beliefs and healthcare decisions, The Park Ridge Center, Illinois 2002.

5- Salute e identità religiose. Per un approccio multiculturale nell'assistenza alla persona. Induismo-Buddhismo-Ebraismo-Cristianesimo- Islam, s.1. 2017.

6- Health Care Providers' Handbook on Muslim Patients, Division of the Chief Health Officer, Queensland Health, $2010 . \quad$ Brisbane Accessed https://www.health.qld.gov.au/_data/assets/pdf_file/0034/155887/islamgde2ed.pdf.

7- Harakas SS. The Orthodox Christian Tradition: Religious Beliefs and Healthcare Decisions, The Park Ridge Center for the Study of Health, Faith, and Ethics, Chicago 1999-2000.

8- Health Care Providers' Handbook on Hindu Patients. Division of the Chief Health Officer, Queensland Health, Brisbane 2011. Accessed on https://www.health.qld.gov.au/_data/assets/pdf_file/0024/156255/hbook-hindu.pdf

9- Health Care Providers' Handbook on Sikh Patients. Division of the Chief Health Officer, Queensland Health, $2011 . \quad$ Brisbane Accessed on https://www.health.qld.gov.au/_data/assets/pdf_file/0019/156042/hbook-sikh.pdf.

10- Harvey C. A Buddhist perspective on health and spirituality, in «Scottish Journal of Healthcare Chaplaincy», 2006, 9, I, pp. 33-35.

11- Du Bose E. The Jehovah's Witness Tradition: religious beliefs and healthcare decisions, ThePark Ridge Center for the Study of Health, Faith, and Ethics, Chicago 2002.

12- Murrelli F. (a cura di), Salute e spiritualità nelle strutture sanitarie, Roma 2017. Accessed onhttp://www.volontariato.lazio.it/documentazione/documenti/79527952saluteSpiritualitaN elleStruttureSanitarie_Pubblicazione.pdf

13- Ebrahim SH, Memish ZA. COVID-19: preparing for superspreader potential among Umrah pilgrims to Saudi Arabia. Lancet. 2020 Mar 14;395(10227):e48. doi: 10.1016/S01406736(20)30466-9.

14- https://www.scientificamerican.com/article/how-superspreading-events-drive-most-covid19-spread1/; accessed on October 2nd, 2020 
15- https://www.scientificamerican.com/article/how-superspreading-events-drive-most-covid19-spread1/; accessed on October 2nd, 2020

16- James A, Eagle L, Phillips C, Hedges DS, Bodenhamer C, Brown R, Wheeler JG, Kirking H. High COVID-19 Attack Rate Among Attendees at Events at a Church - Arkansas, March 2020. MMWR Morb Mortal Wkly Rep. 2020 May 22;69(20):632-635. doi: 10.15585/mmwr.mm6920e2. PMID: 32437338.

17- Memish ZA, Ahmed Y, Alqahtani SA, Ebrahim SH. Pausing superspreader events for COVID-19 mitigation: International Hajj pilgrimage cancellation. Travel Med Infect Dis. 2020 Jul-Aug;36:101817. doi: 10.1016/j.tmaid.2020.101817.

18- Ebrahim SH, Memish ZA. Saudi Arabia's drastic measures to curb the COVID-19 outbreak: temporary suspension of the Umrah pilgrimage. J Travel Med. 2020 May 18;27(3):taaa029. doi: $10.1093 / \mathrm{jtm} / \mathrm{taaa} 029$.

19-Badshah SL, Ullah A, Badshah SH, Ahmad I. Spread of Novel coronavirus by returning pilgrims from Iran to Pakistan. J Travel Med. 2020 May 18;27(3):taaa044. doi: $10.1093 / \mathrm{jtm} / \mathrm{taaa} 044$.

20-Quadri SA. COVID-19 and religious congregations: Implications for spread of novel pathogens. Int J Infect Dis. 2020 Jul;96:219-221. doi: 10.1016/j.ijid.2020.05.007. Epub 2020 May 7.

21- https://www.newyorker.com/news/our-columnists/how-iran-became-a-new-epicenter-of-thecoronavirus-outbreak. accessed on October 2nd, 2020

22- Pavli A, Smeti P, Papadima K, Andreopoulou A, Hadjianastasiou S, Triantafillou E, Vakali A, Kefaloudi C, Pervanidou D, Gogos C, Maltezou HC. A cluster of COVID-19 in pilgrims to Israel. J Travel Med. 2020 Aug 20;27(5):taaa102. doi: 10.1093/jtm/taaa102.

23-Gu Y, Lu J, Yang Z. Pilgrimage and COVID-19: The risk among returnees from Muslim countries. Int J Infect Dis. 2020 Jun;95:457-458. doi: 10.1016/j.ijid.2020.04.066. Epub 2020 Apr 30.

24- Che Mat NF, Edinur HA, Abdul Razab MKA, Safuan S. A single mass gathering resulted in massive transmission of COVID-19 infections in Malaysia with further international spread. J Travel Med. 2020 May 18;27(3):taaa059. doi: 10.1093/jtm/taaa059.

25- https://www.nbcnews.com/news/world/least40-000-quarantined-india-after-single-priestspread-coronavirus-n1171261. accessed on October 2nd, 2020

26- https://www.nst.com.my/news/nation/2020/04/581317/tabligh-gathering-cluster-contributeshighest-positivecovid-19-figures. accessed on October 2nd, 2020 
27- https://www.ndtv.com/india-news/ coronavirus-tablighi-jamaat-30-per-cent-of-coronaviruscases-linked-todelhi-mosque-event-government-2206163. accessed on October 2nd, 2020

28- Jaja IF, Anyanwu MU, Iwu Jaja CJ. Social distancing: how religion, culture and burial ceremony undermine the effort to curb COVID-19 in South Africa. Emerg Microbes Infect. 2020 Dec;9(1):1077-1079. doi: 10.1080/22221751.2020.1769501.

29- Chirico F, Nucera G. An Italian Experience of Spirituality from the Coronavirus Pandemic. J Relig Health. 2020 Oct;59(5):2193-2195. doi: 10.1007/s10943-020-01036-1.

30- Schattner A, Klepfish A. Orthodox Judaism as a Risk Factor of Covid-19 in Israel. Am J Med Sci. 2020 Sep;360(3):304. doi: 10.1016/j.amjms.2020.05.037. Epub 2020 Jun 1.

31- https://www.latimes.com/world-nation/story/2020-04-07/ultra-orthodox-jews-hitdisproportionately-hard-in-israels-coronavirus-outbreak. accessed on October 2nd, 2020

32- https://www.indiatoday.in/ world/story/iskcon-reports-21-coronavirus-cases-5-deaths-in-ukall-hadattended-funeral-gathering-1666032-2020-04-12. accessed on October 2nd, 2020

33- https://www.ilmessaggero.it/italia/nomadi_rom_focolaio_molise_coronavirus_oggi5223348.html. accessed on October 2nd, 2020

34- Iqbal Q, Tareen AM, Saleem F. Religious cliché and COVID-19 management: a barrier for physicians. Br J Gen Pract. 2020 May 28;70(695):278. doi: 10.3399/bjgp20X709961.

35- Mosaferchi S, Sharif-Paghaleh E, Mortezapour A, Heidarimoghadam R. Letter to the Editor: The first Ramadan during COVID-19 pandemic: 1.8 billion Muslims should fast or not? Metabolism. 2020 Jul;108:154253. doi: 10.1016/j.metabol.2020.154253.

36- Javanmard SH, Otroj Z. Ramadan Fasting and Risk of Covid-19. Int J Prev Med. 2020 May 25;11:60. doi: 10.4103/ijpvm.IJPVM_236_20.

37- Hanif S, Ali SN, Hassanein M, Khunti K, Hanif W. Managing People with Diabetes Fasting for Ramadan During the COVID-19 Pandemic: A South Asian Health Foundation Update. Diabet Med. 2020 Jul;37(7):1094-1102. doi: 10.1111/dme.14312.

38-Simon Dein, Kate Loewenthal, Christopher Alan Lewis \& Kenneth I. Pargament (2020) COVID-19, mental health and religion: an agenda for future research, Mental Health, Religion \& Culture, 23:1, 1-9, DOI: 10.1080/13674676.2020.1768725

39- DeSouza F, Parker CB, Spearman-McCarthy EV, Duncan GN, Black RMM. Coping with Racism: a Perspective of COVID-19 Church Closures on the Mental Health of African Americans. J Racial Ethn Health Disparities. 2020 Oct 2:1-5. doi: 10.1007/s40615-02000887-4. 
40-Corpuz JCG. Religions in action: the role of interreligious dialogue in the COVID-19 pandemic. J Public Health (Oxf). 2020 Sep 2:fdaa149. doi: 10.1093/pubmed/fdaa149. Epub ahead of print.

41- DeFranza D, Lindow M, Harrison K, Mishra A, Mishra H. Religion and reactance to COVID19 mitigation guidelines. Am Psychol. 2020 Aug 10. doi: 10.1037/amp0000717.

42- Bruce MA. COVID-19 and African American Religious Institutions. Ethn Dis. 2020 Jul 9;30(3):425-428. doi: 10.18865/ed.30.3.425.

43- https://www.pewresearch.org/fact-tank/2020/04/30/few-americans-say-their-house-ofworship-is-open-but-a-quarter-say-their-religious-faith-has-grown-amid-pandemic/. Accessed on October $2^{\text {nd }}, 2020$

44- Bentzen, Jeanet, In Crisis, We Pray: Religiosity and the COVID-19 Pandemic (May 2020). CEPR Discussion Paper No. DP14824, Available at SSRN: https://ssrn.com/abstract=3615587

45- Levin J. The Faith Community and the SARS-CoV-2 Outbreak: Part of the Problem or Part of the Solution? J Relig Health. 2020 Oct;59(5):2215-2228. doi: 10.1007/s10943-020-01048$\mathrm{X}$

46- Weinberger-Litman SL, Litman L, Rosen Z, Rosmarin DH, Rosenzweig C. A Look at the First Quarantined Community in the USA: Response of Religious Communal Organizations and Implications for Public Health During the COVID-19 Pandemic. J Relig Health. 2020 Oct;59(5):2269-2282. doi: 10.1007/s10943-020-01064-х.

47- Hashmi FK, Iqbal Q, Haque N, Saleem F. Religious Cliché and Stigma: A Brief Response to Overlooked Barriers in COVID-19 Management. J Relig Health. 2020 Jul 8:1-4. doi: 10.1007/s10943-020-01063-y.

48- Galiatsatos P, Monson K, Oluyinka M, Negro D, Hughes N, Maydan D, Golden SH, Teague P, Hale WD. Community Calls: Lessons and Insights Gained from a Medical-Religious Community Engagement During the COVID-19 Pandemic. J Relig Health. 2020 Oct;59(5):2256-2262. doi: 10.1007/s10943-020-01057-w.

49- Ribeiro MRC, Damiano RF, Marujo R, Nasri F, Lucchetti G. The role of spirituality in the COVID-19 pandemic: a spiritual hotline project. J Public Health (Oxf). 2020 Jul 22:fdaa120. doi: 10.1093/pubmed/fdaa120.

50-Imber-Black E. Rituals in the Time of COVID-19: Imagination, Responsiveness, and the Human Spirit. Fam Process. 2020 Sep;59(3):912-921. doi: 10.1111/famp.12581.

51- Frei-Landau R. "When the going gets tough, the tough get-Creative": Israeli Jewish religious leaders find religiously innovative ways to preserve community members' sense of belonging 
and resilience during the COVID-19 pandemic. Psychol Trauma. 2020 Aug;12(S1):S258S260. doi: 10.1037/tra0000822. Epub 2020 Jun 15.

52- Del Castillo FA, Biana HT, Joaquin JJB. ChurchInAction: the role of religious interventions in times of COVID-19. J Public Health (Oxf). 2020 Aug 18;42(3):633-634. doi: 10.1093/pubmed/fdaa086.

53- Modell SM, Kardia SLR. Religion as a Health Promoter During the 2019/2020 COVID Outbreak: View from Detroit. J Relig Health. 2020 Oct;59(5):2243-2255. doi: 10.1007/s10943-020-01052-1.

54- https://www.merckmanuals.com/home/older-people\%E2\%80\%99s-health-issues/socialissues-affecting-older-people/religion-and-spirituality-in-older-people. Accessed on October $28^{\text {th }}, 2020$

55- Koenig HG. Ways of Protecting Religious Older Adults from the Consequences of COVID19. Am J Geriatr Psychiatry. 2020 Jul;28(7):776-779. doi: 10.1016/j.jagp.2020.04.004.

56- Hong BA, Handal PJ. Science, Religion, Government, and SARS-CoV-2: A Time for Synergy. J Relig Health. 2020 Oct;59(5):2263-2268. doi: 10.1007/s10943-020-01047-y.

57- Carey LB, Cohen J. The utility of the WHO ICD-10-AM pastoral intervention codings within religious, pastoral and spiritual care research. Journal of Religion and Health. 2015;54:17721787. doi: 10.1007/s10943-014-9938-8.

58- https://brooklyneagle.com/articles/2020/10/07/opinions-observations-amid-covid-19-spikein-ultra-orthodox-areas-history-may-explain-reluctance-to-restrictions/. Accessed on October $28^{\text {th }}, 2020$

59- https://www.state.gov/covid-19-and-religious-minorities-pandemic-statement/. Accessed on October $28^{\text {th }}, 2020$

$60-$ 